$\begin{array}{r}\begin{array}{l}\text { Interdisciplinary Contexts of Special Pedagogy } \\ \text { NUMBER 26/2019 }\end{array} \\ \text { ANIDA SZAFRAŃSKA } \\ \text { University of Silesia in Katowice } \\ \hline\end{array}$

\title{
Support Teachers in the Education of Students with Autism and Asperger Syndrome in Integrated and Mainstream Schools
}

\begin{abstract}
Anida Szafrańska, Support Teachers in the Education of Students with Autism and Asperger Syndrome in Integrated and Mainstream Schools. Interdisciplinary Contexts of Special Pedagogy, no. 26, Poznań 2019. Pp. 59-80. Adam Mickiewicz University Press. ISSN 2300-391X. e-ISSN 2658-283X. DOI: https://doi.org/10. 14746/ikps.2019.26.03
\end{abstract}

The article presents a pilot study of the tasks of support teachers in relation to students with autism, including those with Asperger's syndrome. Data contained in the Educational Information System shows a significant increase in the number of students with this type of disorder studying in integrated units and mainstream schools. The education of students with autism and Asperger's syndrome is difficult due to their deficits in the cognitive sphere, as well as problems in social and emotional functioning. When carried out in an appropriate manner, with relevant professional support, the inclusion of autistic children may be beneficial both for the children's intellectual, social and emotional development, as well as other students.

KEY WORDS: autism spectrum disorders, education of students with ASD, integrated and inclusive education, support teacher

\section{Introduction}

In accordance with the ICD 10 classification in force in Poland, autism and Asperger syndrome belong to the group of pervasive 
developmental disorders (PDD). ${ }^{1}$ Currently, the term autism spectrum disorders (ASD), used in the DSM - 5 classification ${ }^{2}$, is applied more and more frequently, blurring the boundaries between the most common pervasive developmental disorders, i.e. autism, Asperger syndrome and PDD not defined otherwise (PDD-NOS). ${ }^{3}$ In this classification, autism spectrum disorders belong to neurodevelopmental disorders and the axial symptoms include persistent deficits in social communication and social relations in many environments, as well as limited, repetitive patterns of behaviour or activity. ${ }^{4}$ The co-existence of intellectual disabilities which affects $55 \%$ of persons with $\mathrm{ASD}^{5}$, mental disorders that may be present in $70 \%$ of children ${ }^{6}$ and sensory disturbances that can dominate all the activities of a person 7 are a serious problem. Autism spectrum disorders are a significant social problem. The majority of epidemiological studies conducted after the year 2000 indicate the prevalence of a wide spectrum of autism. They show that the average preva-

${ }^{1}$ Międzynarodowa Statystyczna Klasyfikacja Chorób i problemów Zdrowotnych. Rewizja 10 (International Statistical Classification of Diseases and Health Problems. Revision 10), WHO 2008, p. 248.

2 P. Gałecki, Ł. Święcicki, (academic supervision, Polish ed.), Kryteria diagnostyczne z DSM 5: Desk Reference., Wydawnictwo Edra Urban \& Partner. Wrocław 2015, pp. 24-28.

${ }^{3}$ A. Klin, Typologia zaburzeń ze spektrum. Aspekty teoretyczne, badawcze i kliniczne, [in:] Diagnoza zaburzeń ze spektrum autyzmu, ed. S. Goldstein, Jack A. Naglieri, S. Ozonoff, Wydawnictwo Uniwersytetu Jagiellońskiego, Kraków 2017, p. 126.

${ }^{4}$ P. Gałecki, Ł. Święcicki, (academic supervision, Polish ed.), Kryteria diagnostyczne z DSM 5..., op. cit., pp. 24-25.

${ }^{5}$ L.G. Klinger, S.E. O’Kelly, J.L. Mussey, Diagnoza funkcjonowania intelektualnego w zaburzeniach ze spektrum autyzmu, [in:] Diagnoza zaburzeń ze spektrum autyzmu, ..., op. cit. pp. 262.

${ }^{6}$ R.E Rosenberg, W.E. Kaufmann, J.K. Law, P.A. Law, Parent Report of Community Psychiatric Comorbid Diagnoses in Autism Spectrum Disorders, "Autism Research and Treatment", 2011 Aug. 18, <https://www.ncbi.nlm.nih.gov/pmc/articles/PMC 3420588/> accessed 8 February 2018. Cf. M. Płatos (ed.), Ogólnopolski spis autyzmu. Sytuacja młodzieży $i$ dorostych $z$ autyzmem w Polsce, Wydawca Stowarzyszenie Innowacji Społecznych „Mary i Max”, Warszawa 2016, pp. 38-40; pp. 77-79.

7 B. Nason, Porozmawiajmy o autyzmie. Przewodnik dla rodziców i specjalistów, Kraków 2017, p. 149. 
lence of ASD is 62/10000. ${ }^{8}$ In Poland, there is a noticeable increase in the number of children assessed as requiring special education due to the diagnosis of autism or Asperger's syndrome and their participation in education in integrated units and mainstream schools. Thus, at the end of September 2011 in primary and lower secondary schools a total of 3811 and in 2018 as many as 21313 students were reported. Without addressing the subject of determinants affecting the increase in the number of diagnoses and issued decisions on the need for special education, it can be said, travestying a statement by I. Chrzanowska, that students with autism spectrum disorders are not a trend but the reality of the Polish school". ${ }^{9}$

\section{Students with autism spectrum disorders}

Regardless of the classification adopted, when speaking of pervasive developmental disorders (ICD 10) or, more broadly, autism spectrum disorders (DSM-5), we are talking about early, neurodevelopmental, extensive disorders covering all spheres of social functioning, communication, and various aspects of cognitive and adaptive functioning. ${ }^{10} \mathrm{~F}$. Volkmar and A. Klin report that "people with PDD may have profound intellectual disabilities, as well as extremely high levels of IQ: lack of speech and excessive talkativeness; extremely strong social isolation and an inability to refrain from making contact with others, albeit in an inappropriate way; and their lives may be both dominated by stereotypical movements or repetitive behaviours, as well as by learning about unusual topics". ${ }^{11}$

${ }^{8}$ Quoted after: F. Rybakowski, A. Białek, I. Chojnicka et al., Zaburzenia ze spektrum autyzmu - epidemiologia, objawy, wspótzachorowalność i rozpoznawanie, „Psychiatria Polska" 2014, 48(4), p. 655.

${ }^{9}$ I. Chrzanowska, Wstęp, „Interdyscyplinarne Konteksty Pedagogiki Specjalnej", 2013, No. 1, p. 7.

${ }^{10}$ A. Klin, Typologia zaburzeń ze spectrum. Aspekty teoretyczne, badawcze i kliniczne, [in:] Diagnoza zaburzeń ze spektrum autyzmu, op. cit., p. 125.

${ }^{11}$ Quote after: A. Klin, op. cit., p. 125. 
Students with autism, including Asperger's syndrome, are classified as students with special educational needs. These needs result from social and communication deficits and behavioural problems such as hyperactivity, limited attention, impulsivity, aggression and auto-aggressive behaviour, as well as other disorders, including intellectual disabilities, sensory problems and possible health problems. The diversity and significant intensification of these deficits is a unique challenge for teachers and therapists. When organising the education process of this group of students it is therefore important to recognise the difficulties experienced by individual students and to manage the education process in such a way that they can use their strengths to develop their intellectual, physical and emotional potential.

\section{Education of students with autism and Asperger syndrome ${ }^{12}$}

The basic legal act regulating the education of children and youth with disabilities is the Act of 14 December 2016 Education Law. ${ }^{13}$ Detailed rules are contained in the Regulation of Minister of National Education of 9 August 2017 on the conditions of organizing education, upbringing and care for children and youth with disabilities, socially maladjusted and at risk of social maladjustmen. ${ }^{14}$ According to this document, students with autism, including Asperger's syndrome, assessed as requiring special education may attend special, integrated and mainstream kindergartens and schools. ${ }^{15}$ The final decision on the choice of the form of education is made by the parents or legal guardians.

12 In accordance with the nomenclature used in the educational documents in force and regulations of the Ministry of Education, I will use the terms autism and Asperger syndrome in the further part of the study.

13 Journal of Laws of 2017, item 59.

14 Journal of Laws of 2017, item 1578.

15 Regulation of the Minister of National Education of 7 September 2017 on opinions and decisions issued by adjudicating panels operating in public psychological and pedagogical counselling centres; Journal of Laws of 2017, item 1743. 
The increasing number of students with autism, including those with Asperger's syndrome, in integrated and mainstream education is a reflection of the general trend of moving away from segregated education ${ }^{16}$ to integrated and inclusive education. The IBE (Educational Research Institute) Report on educational pathways of people with disabilities provided interesting data. School directors pointed to integrated schools as the most appropriate form of learning for students with autism and Asperger's syndrome. Among the key conclusions were the very good opinions of the vast majority of parents on the schools attended by their children. Positive opinions were expressed particularly in the case of integrated and special schools. ${ }^{17}$ However, the report prepared by the Synapsis Foundation shows that in the school year 2005/2006 the majority of autistic children attended mainstream schools. 18

Integration is understood as introducing "previously segregated children to the mainstream", and inclusion refers to the situation where children with disabilities are brought up and educated together with their able peers from the very beginning, and it is the school that adapts itself to their needs...". ${ }^{19}$ J. Głodkowska defines inclusive education as "a process of joint education of pupils with special educational needs and their healthy peers, while ensuring a sense of belonging to the school community and providing the necessary support (technical, methodological, psychosocial, organisational) for them as a result of their disability..$^{20}$ Inclusive education

16 I. Chrzanowska, Pedagogika specjalna. Od tradycji do wspótczesności, Oficyna Wydawnicza „Impuls”, Kraków 2015, p. 533.

17 P. Grzelak, P. Kubicki, M. Orłowska, Realizacja badania ścieżek edukacyjnych niepetnosprawnych dzieci, uczniów i absolwentów. Raport końcowy, Educational Research Institute in Warsaw, 2014.

18 Quote after: I Chrzanowska, Wiedza na temat autyzmu wśród obecnych i przysztych pedagogów a dylemat wspólnego ksztatcenia $i$ integracji w wymiarze edukacyjnym, „Rocznik Lubuski” 2012, Vol. 38, part 2, p. 112 (105-114).

19 A. Firkowska-Mankiewicz, G. Szumski, Pedagogika specjalna i system ksztatcenia osób z niepetnosprawnościami w Polsce, [in:] Pedagogika specjalna 2. Podręcznik akademicki, D.D. Smith, Wydawnictwo PWN, Warszawa 2009, p. 333.

20 J. Głodkowska, W poszukiwaniu modelu edukacji właczającej, „Meritum” 2009, No. 2(13), p. 6. 
takes place in a district school, in a regular classroom, on the basis of a common but individualised curriculum. The lead teacher is responsible for the education of all students. Both students and teachers can count on the flexible help of a specialist. ${ }^{21}$

The variety of symptoms in the case of children with ASD, and therefore the diversity of needs, means that there is no single educational method or rule that applies to all children with ASD. However, according to Robbins et al., ASD children should be integrated as early as possible into the same educational environment and activities as neurotypical children to facilitate the development of social interaction between peers. ${ }^{22}$ Inclusion can be beneficial for some students because it supports social, emotional and cognitive development. ${ }^{23}$ However, inclusion does not always have positive effects. This happens when the child or pupil does not have sufficient social skills to participate in activities with others, or when the educational environment is not prepared to work with the pupil. Researchers agree that it is not advisable for some students to participate in a mainstream classroom and that they will benefit significantly more from learning in other ways. ${ }^{24} \mathrm{~A}$ similar view is represented, among others, by A. Zamkowska and G. Dryżałowska, who mention the factors limiting student participation in integrated education. These are: the type and degree of disability, the level of development, limitations in the family environment. ${ }^{25}$ Numerous studies on integrated and inclusive education of pupils with ASD reveal

21 S. Olszewski, K. Parys, Rozumieć chaos. Rzecz o terminach i znaczeniach im nadawanych w pedagogice specjalnej, Wydawnictwo Naukowe Uniwersytetu Pedagogicznego in Krakow, Kraków 2016, p. 193.

22 E. Boujut, A. Dean, A. Grouselle, E. Cappe, Comparative Study of Teachers in Regular Schools and Teachers in Specialized Schools in France, Working with Students with an Autism Spectrum Disorder: Stress, Social Support, Coping Strategies and Burnout, J Autism Dev Disord (2016) 46, p. 2875.

23 Ibid, p. 2886.

24 J. Evans, I. Lunt, Inclusive education: are there limits?, "European Journal of Special Need Education" 2002, 17(1), pp. 1-14.

${ }^{25}$ Quote after: I. Chrzanowska, Pedagogika specjalna..., op. cit., p. 539. 
many barriers to this process also for better-functioning pupils. Research carried out among teachers has provided interesting data. Although all respondents were positive about the inclusion of persons with high-functioning ASD, they also pointed to barriers. These included: the features of a student with ASD, including behavioural problems, peer impact in terms of aggressive behaviour, and staffing resources. ${ }^{26}$

Teachers are one of the links in the process of school transformation and development of inclusive education. They are the ones who respond to the many expectations and requirements concerning competences and attitudes towards students with disabilities and their education. As Z. Janiszewska-Nieścioruk writes, "the teachers should be perceived as the main creators of this inclusion" 27 , "the quality of inclusive education... is conditioned by the quality of teaching staff, their professionalism as expressed in their openness to the needs of each pupil...".28 The tasks of the teacher co-organizing the education of students with disabilities, including those with autism and students with Asperger's syndrome include: conducting educational activities together with the teacher, and integrated activities and activities specified in the curriculum together with other teachers and specialists, educational work, as well as participation in such activities as needed; providing assistance to teachers conducting educational activities and to teachers, specialists implementing integrated activities and activities specified in the curriculum, in choosing forms and methods of work; conducting activities appropriate to individual developmental and educational needs and the psychophysical abilities of the students, in particular remedial, rehabilitation and sociotherapeutic activities; participation

${ }_{26}$ J.M. Sansosti, F. Sansosti, Inclusion for Students with High-functioning Autism Spectrum Disorders: Definitions and Decision Making, "Psychology in the Schools" Vol. 49(10), 2012, p. 929.

27 Z. Janiszewska-Nieścioruk, (Nie)dojrzałość proinkluzyjnych zmian w kształceniu osób z niepetnosprawnością, "Niepełnosprawność. Dyskursy pedagogiki specjalnej”, No. 22/2016, p. 56.

${ }^{28}$ Ibidem, p. 57. 
in the work of the IPET development team. ${ }^{29}$ The list of tasks is quite general and is only a framework for the activities of a teacher co-organising special education.

\section{Own research}

The research was conducted in the Upper Silesian Agglomeration in the following cities: Katowice, Chorzów, Tychy, Sosnowiec, Bytom, Piekary Śląskie. The research involved women, 75 teachers, 42 of whom were primary and lower secondary school teachers (one institution) with integrated units and 33 teachers of mainstream primary schools. The selection of the sample was purposeful, the research involved teachers working with students with autism and Asperger's syndrome. The studies were pilot studies.

The aim of the research was to identify the tasks performed by teachers co-organising the process of education of students with autism, including Asperger's syndrome.

The research was conducted by means of a diagnostic survey with the use of a self-developed questionnaire. The research was based on the positivistic research paradigm.

\section{Results of research}

The following abbreviations were used in the tables:

IS - schools with integrated units

MS - mainstream schools

In schools with integrated classes, nearly $70 \%$ of the respondents are nominated and certified teachers with work experience ranging from 16 to 35 years and experience as a support teacher from 2 to

${ }^{29}$ Regulation of the Minister of National Education of 9 August 2017 on the conditions for organising education, upbringing and care for children and youth with disabilities, socially maladjusted and at risk of social maladjustment $\S 7$ section 7 and $\S 5$ section 4 (Journal of Laws of 2017, item 1578). 
18 years. In mainstream schools, $51.5 \%$ are nominated and certified teachers with 10-35 years of work experience, but with a much shorter period of experience as a support teacher (1-3 years). The differences in the length of work experience in the position of a support teacher between both types of schools result from the provisions of the Regulation ${ }^{30}$, according to which a teacher coorganizing the education process could be employed only from 2016.

Table 1. Degree of professional promotion

\begin{tabular}{|l|c|c|c|c|c|c|}
\hline \multirow{2}{*}{$\begin{array}{c}\text { Degree } \\
\text { of professional } \\
\text { promotion }\end{array}$} & \multicolumn{2}{|c|}{ IS } & \multicolumn{2}{c|}{ MS } & \multicolumn{2}{c|}{ Total } \\
\cline { 2 - 8 } & $\mathrm{T}=42$ & $\%$ & $\mathrm{~T}=33$ & $\%$ & $\mathrm{~T}=75$ & $\%$ \\
\hline Teacher trainee & 2 & 4.8 & 5 & 15.1 & 7 & 9.3 \\
\hline Contract teacher & 12 & 28.6 & 11 & 33.3 & 23 & 30.7 \\
\hline Nominated teacher & 7 & 16.6 & 7 & 21.2 & 14 & 18.7 \\
\hline Certified teacher & 21 & 50 & 10 & 30.3 & 31 & 41.3 \\
\hline
\end{tabular}

Source: Own research.

Table 2. Teacher training

\begin{tabular}{|l|c|c|c|c|c|c|}
\hline \multirow{2}{*}{$\begin{array}{c}\text { Completed } \\
\text { faculties }\end{array}$} & \multicolumn{2}{|c|}{ IS } & \multicolumn{2}{c|}{ MS } & \multicolumn{2}{c|}{ Total } \\
\cline { 2 - 7 } & $\mathrm{T}=42$ & $\%$ & $\mathrm{~T}=33$ & $\%$ & $\mathrm{~T}=75$ & $\%$ \\
\hline Special education & 19 & 45.2 & 15 & 45.5 & 34 & 45.3 \\
\hline Other faculties & 23 & 54.8 & 18 & 54.5 & 41 & 54.7 \\
\hline
\end{tabular}

Source: Own research.

Almost half of the respondents in both groups completed their master's studies in one of the sub-disciplines of special education. Among the teachers of integration classes, 19 persons completed studies in oligophrenopedagogy, rehabilitation pedagogy, thera-

${ }^{30}$ Journal of Laws of 2017, item 1578. 
peutic pedagogy, surdopedagogy (deaf education). The remaining 23 persons graduated from other fields of study, mainly subject studies. Among the teachers of mainstream schools, 15 persons completed social rehabilitation pedagogy, including 4 persons educated in early school education and oligophrenopedagogy, 18 persons completed other fields of study.

All respondents declare that they have additional qualifications obtained during post-graduate studies and/or qualification courses. Among all the teachers, 6 persons completed post-graduate studies in 3 specialisations of special education.

With regard to the qualifications required for a teacher coorganising special education for students with autism, the existing legal regulations ${ }^{31}$ require preparation in the field of special education, but do not specify the specialisation precisely. Taking the above into account, 72 teachers have the required qualifications obtained as a result of graduating from master's or post-graduate studies.

It should be added that all teachers have completed at least several different forms of professional training and most of the respondents have completed specialist training in working with students with the autism spectrum. These include: social skills training, students with autism in a mainstream school, autism from " $a$ " to " $z$ ", how to work with a student with autism, how to support a student with autism and Asperger's syndrome, methods of working with an autistic student, methods of alternative communication.

The declaration of undertaking further education is also noteworthy.

The included data show that teachers are very interested in professional development. Among those surveyed, 25 teachers of integration units declare the need for further education in the area of working with ASD students. These are people with work experience of up to 25 years. However, 17 persons $(40.5 \%)$ do not plan or have no opinion on improving their qualifications. This group includes

$31<$ https://www.nadzor-pedagogiczny.pl/porada/jakie-kwalifikacje-musi-posia dac-nauczyciel-wspoma/9285>. 
Table 4. Declared need for further education

\begin{tabular}{|l|c|c|c|c|c|c|}
\hline \multirow{2}{*}{$\begin{array}{c}\text { Response } \\
\text { categories }\end{array}$} & \multicolumn{2}{c|}{ IS } & \multicolumn{2}{c|}{ MS } & \multicolumn{2}{c|}{ Total } \\
\cline { 2 - 7 } & $\mathrm{T}=42$ & $\%$ & $\mathrm{~T}=33$ & $\%$ & $\mathrm{~T}=75$ & $\%$ \\
\hline Yes & 25 & 59.5 & 33 & 100 & 58 & 77.3 \\
\hline No & 7 & 16.7 & - & - & 7 & 9.3 \\
\hline I have no opinion & 10 & 23.8 & - & - & 10 & 13.3 \\
\hline
\end{tabular}

Source: Own research.

mainly persons with longer work experience, of over 25 years, but also those with short work experience. In the case of the first group, long work experience and resulting professional experience, as well as a large number of training courses mean that these persons do not see the need for further education. The second group includes people who are facing a decision on staying in a given position or a change. The declaration of further education by teachers of mainstream schools is particularly noteworthy. This need was reported by $100 \%$ of respondents.

Teachers of both types of schools are interested in training concerning the following areas: working with children with ASD, diagnosing these disorders, training in social skills, sexuality of children and youth, methods of working with people with autism, tutoring and special education sub-disciplines other than those already known. Some of the respondents did not specify the area of further education, expecting proposals from the school. One of the respondents said: trainings and courses on an ongoing basis, when I realise I have a lack of knowledge, I feel insecure.

In total, 81 students with autism and students with Asperger's syndrome are assisted by support teachers, including 48 in integration units and 33 in mainstream schools. In the first group, 6 teachers support 2 students, the remaining ones - one. In the case of mainstream schools, this situation does not occur. In integrated units more than half of the students have a diagnosis of autism or multiple disability and 12 persons have a diagnosis of Asperger's syndrome. In mainstream classes, 30 students are diagnosed with 
Asperger's syndrome and 3 with autism. It should be noted that teachers from integrated classes also perform their functions in relation to other children assessed as requiring special education.

Table 6. Students with autism, including Asperger's syndrome, supported by a teacher

\begin{tabular}{|l|c|c|c|}
\hline \multicolumn{1}{|c|}{ Response categories } & IS & MS & Total \\
\hline Autism & 27 & 3 & 30 \\
\hline Asperger's Syndrome & 12 & 30 & 42 \\
\hline $\begin{array}{l}\text { Multiple disability, including: } \\
\text { - autism and motor disability } \\
\text { - Asperger's syndrome and hearing loss }\end{array}$ & 9 & - & 9 \\
\hline
\end{tabular}

Source: Own research.

Taking into account the challenges faced by teachers in relation to the specific problems of children with autism and Asperger's syndrome, a question was asked about the way in which students communicate with each other and about the occurrence of difficult behaviours. These two areas of functioning are important for the organization of work in class, both in integration and mainstream classrooms, as well as for building friendly relations.

It was found that in integrated classes 35 out of 48 pupils show difficult behaviours, mainly disruptive behaviours. Teachers mentioned: loud conversations, refusal to cooperate, refusal to perform a task, slow pace of work, walking around the classroom, laughing, clapping. 7 students sometimes behave aggressively (push and hit their peers) and 2 show aggressive and self-aggressive behaviours (not specified), but according to the teachers these can be controlled. More serious communication problems occur in the case of 7 students (quiet speech, single words, gestures). In mainstream classes, 24 students show disturbing behaviours (slow pace of work, refusal to perform a task), including 4 students with additional aggressive behaviours (harassment, use of vulgar words). In this group all students communicate verbally, including 2 speaking single words. 
Another issue was to identify the special needs of the students in relation to whom the respondents acted as a support teacher. The majority of respondents mentioned the following issues: problems specific to the functioning of people with autism spectrum disorders, problems with behaviour, problems with mastering emotions, also stating the resulting needs, e.g. help in organizing work in class, motivating intellectual effort, anchored attention, calming down, help in planning work, explaining texts, checking the understanding of the text, help in accepting changes by explaining them, calming down, calming down emotions. 6 persons mentioned social skills building and 2 persons mentioned peer relations building.

As can be seen, most of the problems identified by teachers are related to the didactic sphere. The survey contains less information on needs resulting from social functioning deficits and emotional problems apart from such general statements as psychological support, emotional support (2 statements), accompaniment during breaks, conversation in a situation of breakdown (1 statement).

Another aspect of the study were actions taken in relation to students.

Table 7. Support for students with autism, including Asperger's syndrome, according to the respondents

\begin{tabular}{|l|c|c|}
\hline \multirow{2}{*}{ Response categories } & IS & MS \\
\cline { 2 - 3 } & $\begin{array}{c}\text { number } \\
\text { of responses }\end{array}$ & $\begin{array}{c}\text { number } \\
\text { of responses }\end{array}$ \\
\hline Creating the best possible learning environment & 20 & 10 \\
\hline Creating an optimal stimulating environment & 20 & 8 \\
\hline Recognising and responding to the individual needs of the students & 29 & 18 \\
\hline $\begin{array}{l}\text { Adaptation of forms, methods and means of teaching to the abilities } \\
\text { and individual needs of the students }\end{array}$ & 42 & 33 \\
\hline Adaptation of educational requirements & 40 & 22 \\
\hline
\end{tabular}

Source: Own research. Respondents chose more than one response category. 
The categories of support for autistic and Asperger syndrome students presented in Table 7 show that most of the choices concern the adaptation of forms, methods and means of teaching to the abilities and individual needs of the student (42 and 33), the adaptation of educational requirements (40 and 22) and the recognition and response to the individual needs of the student (29 and 18). These categories are specific to activities related to the education of students with special educational needs and hence the numerous indications are not surprising. The category most rarely chosen, especially by teachers of mainstream schools, were activities related to the creation of an optimal stimulating environment and the best possible learning environment, which, due to the specificity of functioning of students with ASD, including sensory disorders and behavioural problems is very important.

Table 8. The tasks of support teachers

\begin{tabular}{|l|c|c|}
\hline \multicolumn{1}{|c|}{ Response categories } & IS & MS \\
\cline { 2 - 3 } & $\begin{array}{c}\text { number of } \\
\text { responses }\end{array}$ & $\begin{array}{c}\text { number of } \\
\text { responses }\end{array}$ \\
\hline Supporting students in their educational activities & 42 & 33 \\
\hline Conducting revalidation classes & 15 & 18 \\
\hline Conducting specialist classes & 12 & 6 \\
\hline $\begin{array}{l}\text { Carrying out a multi-specialist assessment of the level of student } \\
\text { functioning }\end{array}$ & 32 & 24 \\
\hline $\begin{array}{l}\text { Informing teachers about the progress and difficulties of the stu- } \\
\text { dent in the classroom }\end{array}$ & 32 & 22 \\
\hline Helping teachers to adapt their educational requirements & 30 & 19 \\
\hline $\begin{array}{l}\text { Participation in the work of a team of teachers and specialists work- } \\
\text { ing with students, in the development and modification of IPET }\end{array}$ & 42 & 33 \\
\hline Preparation of materials and aids for classes, & 42 & 33 \\
\hline $\begin{array}{l}\text { Participation in meetings with parents, informing parents about } \\
\text { the students' progress, instructing them to work at home }\end{array}$ & 38 & 28 \\
\hline Other, what kind? & no indications & no indications \\
\hline
\end{tabular}

Source: Own research. Respondents chose more than one response category. 
Most of the responses were related to categories associated with the preparation of documentation concerning the implementation of special education, tasks related to fulfilling the duties of a teacher supporting students during lessons, preparation of didactic materials.

In the next section, teachers were asked to briefly describe the actions they take in relation to students during the educational activities. All the respondents answered this question by mentioning: formulating simple instructions, avoiding mental short-cuts, metaphors, precise expectations, additional explanations, exercises in reading comprehension, dividing the material into smaller units, choosing didactic aids, preparing additional aids, checking the correctness and completeness of the notes, assisting in organizing work during the lesson, adjusting tests, work cards, explaining, precise expectations and assessments. One of the respondents wrote: I am constantly observing, discreetly, I do not impose myself and I react only when necessary.

As far as the implementation of activities in the social and emotional sphere is concerned, 32 teachers of integration classes and 24 mainstream classes provided their answers. The respondents mentioned: taking care of a good atmosphere in the classroom, using positive reinforcements, encouraging to work, encouraging to take up activity, reminding students about not interrupting the lesson, motivating them to be as independent as possible, showing approval of proper behaviours, using praise, calming down, controlling emotions, showing how to behave, making sure that the students observe the rules, helping to solve conflicts, helping in contacts with peers.

No significant differences were noted in the statements of teachers of both groups.

31 teachers of integrated classes and 17 teachers of mainstream classes answered the question about supporting students outside their lessons, mentioning such activities as: conversations with students, cooperation with parents, involvement in important school events, ensuring safety during events, excursions, group trips, stay in the school common room. One person answered: we are in constant contact, even after class, and another one said: I give tips on how to use the activity plan, tips for homework, I provide help in doing homework, show how to search for information. 
The statements show that the activities undertaken outside the classroom by the majority of teachers do not exceed the customary activities concerning all students.

An important aspect of the support teacher's work is cooperation with teachers, school pedagogues, parents or legal guardians of the child, as well as other persons related to education and psychological and pedagogical support.

Among the people with whom they cooperate are: pedagogues and psychologists from the psychological-educational counselling centre, teachers conducting specialist classes and methodologists.

Another aspect was the evaluation of cooperation with teachers and school pedagogues.

Table 9. Experience of cooperation between support teachers and teachers

\begin{tabular}{|l|c|c|c|c|c|c|}
\hline \multirow{2}{*}{\begin{tabular}{c}
\multirow{2}{*}{$\begin{array}{c}\text { Response } \\
\text { categories }\end{array}$} \\
\cline { 2 - 7 }
\end{tabular}} & \multicolumn{2}{c|}{ IS } & \multicolumn{2}{c|}{ MS } & \multicolumn{2}{c|}{ Total } \\
\hline Very good & 21 & 50.0 & 14 & 42.4 & 35 & 46.7 \\
\hline Good & 11 & 26.2 & 13 & 39.4 & 24 & 32.0 \\
\hline Correct & 10 & 23.8 & 6 & 18.2 & 16 & 21.3 \\
\hline Rather negative & - & - & - & - & - & - \\
\hline Negative & - & - & - & - & - & - \\
\hline
\end{tabular}

Source: Own research.

Table 9. Experience of cooperation between support teachers and school pedagogues

\begin{tabular}{|c|c|c|c|c|c|c|}
\hline \multirow{2}{*}{$\begin{array}{l}\text { Response } \\
\text { categories }\end{array}$} & \multicolumn{2}{|c|}{ IS } & \multicolumn{2}{|c|}{ MS } & \multicolumn{2}{|c|}{ Total } \\
\hline & $\mathrm{T}=42$ & $\%$ & $\mathrm{~T}=33$ & $\%$ & $\mathrm{~T}=75$ & $\%$ \\
\hline Very good & 23 & 54.8 & 15 & 45.4 & 38 & 50.7 \\
\hline Good & 10 & 23.8 & 11 & 33.3 & 21 & 28.0 \\
\hline Correct & 9 & 21.4 & 7 & 21.2 & 16 & 21.3 \\
\hline Rather negative & - & - & - & - & - & - \\
\hline Negative & - & - & - & - & - & - \\
\hline
\end{tabular}

Source: Own research. 
The data contained in Tables 9 and 10 show that the vast majority of teachers in both types of schools declare good and very good experiences of cooperation with leading teachers and school pedagogues. A positive phenomenon is the lack of negative assessments of cooperation between teachers.

Support teachers also assessed their cooperation with parents, who should be considered as an important link in the education of children with disabilities.

Table 11. Assessment of cooperation between the support teacher and the student's parents

\begin{tabular}{|c|c|c|c|c|c|c|}
\hline \multirow{2}{*}{$\begin{array}{l}\text { Response } \\
\text { categories }\end{array}$} & \multicolumn{2}{|c|}{ IS } & \multicolumn{2}{|c|}{ MS } & \multicolumn{2}{|c|}{ Total } \\
\hline & $\mathrm{T}=42$ & $\%$ & $\mathrm{~T}=33$ & $\%$ & $\mathrm{~T}=75$ & $\%$ \\
\hline Very good & 16 & 38.1 & 9 & 27.3 & 25 & 33.3 \\
\hline Good & 14 & 33.3 & 12 & 36.4 & 26 & 34.7 \\
\hline Correct & 12 & 28.6 & 10 & 30.3 & 22 & 29.3 \\
\hline Rather negative & - & - & 2 & 6.0 & 2 & 2.07 \\
\hline Negative & - & - & - & - & - & - \\
\hline
\end{tabular}

Source: Own research.

The analysis of the data contained in the table shows that the vast majority evaluates this cooperation as very good and good, although nearly $30 \%$ considered it to be correct and two teachers answered "rather negative". The majority of these persons are teachers with short work experience.

An important factor in working with a student with autism and Asperger's syndrome is the support received. When asked about support in the implementation of tasks of the support teacher, 6 teachers of mainstream schools answered that they do not receive such support, 2 persons receive support from the employees of psychological and pedagogical counselling centres and 25 persons indicated other teachers, as well as the school pedagogue and school psychologist. In the group of teachers from integrated classes, 
37 persons receive support, while 15 teachers have more numerous and more diverse sources of support. These include other teachers and persons who are part of teams developing individual educational and therapeutic programmes, including a pedagogue, a psychologist, a speech therapist, employees of a psychological and pedagogical counselling centre. 8 teachers attend meetings of support groups organized by psychological-educational counselling centres. 5 persons from this group do not receive support.

\section{Conclusion}

The conducted pilot studies revealed that teachers undertake tasks related to students with autism and Asperger's syndrome resulting from the Regulation.

Almost all the respondents declared completion of master's and postgraduate studies that qualify them to work as support teachers for students with autism and Asperger syndrome. The surveyed teachers undertake activities related to professional development, including broadening and deepening of qualifications. For most of them the motivation for further education includes social needs and the requirements related to the education reform, for others - interest in educating specific groups of students. On the basis of the research it has been established that the most desirable subject matter of training is the broadly understood work with students with autism spectrum disorders. In the surveyed group, some teachers were not interested in further professional development, which may be related to their long work experience, and in other cases, the fact that the position of a support teacher may only be a stage in their professional career.

Research shows that in the integrated and mainstream schools, in which the surveyed teachers are employed, there are children who generally function better, most of them communicate verbally and present a higher level of intellectual functioning (including children with Asperger's syndrome). Most of these students attend mainstream schools. 
Teachers correctly identify students' needs, however teachers of integrated classes do it better, which may result from greater experience.

The occurrence of difficult behaviours in students may be worrying, as this is one of the factors hindering the integration process. In this context, teachers' statements about their ability to deal with such behaviours should be read as a mitigating factor.

The respondents mentioned a number of activities undertaken to support students during and after classes, and when describing specific activities they mentioned activities focused on the didactic sphere and, although to a lesser extent, on social and emotional issues.

In the context of the occurrence of difficult behaviours, it is disturbing that less than half of the respondents indicated such elements of supporting the education of autistic students as creating the best possible learning and stimulation environment. The results suggest that most teachers either do not see the need for a wellprepared learning environment or do not see themselves as those who can take action to adapt the place or arrange the space. It may, therefore, be concluded that this aspect of support teachers' work should be given greater consideration in training.

Positive results were obtained in the scope of cooperation between teachers and other teachers, pedagogues, psychologists and employees of psychological and pedagogical counselling centres. Slightly lower ratings were given by the respondents with regard to cooperation with parents, however, also in this area the results should be considered as positive. The importance of cooperation between teachers and parents should be considered as a significant element facilitating the child's education process. Good cooperation builds trust, integrates, creates a platform for joint activities for the benefit of the child and the whole school community.

The vast majority of respondents can count on support and assistance in their difficult work, while many teachers have created a network of support consisting of teachers and other people involved in the education of students with autism. 
The presented results of the pilot studies have shown many problems which may be an interesting field of research for special educators.

\section{Bibliography}

[1] Boujut E., Dean A., Grouselle A., Cappe E., Comparative Study of Teachers in Regular Schools and Teachers in Specialized Schools in France, Working with Students with an Autism Spectrum Disorder: Stress, Social Support, Coping Strategies and Burnout, J Autism Dev Disord (2016) 46.

[2] Chrzanowska I., Wstęp, „Interdyscyplinarne Konteksty Pedagogiki Specjalnej”, 2013, No. 1.

[3] Chrzanowska I., Pedagogika specjalna. Od tradycji do wspótczesności, Oficyna Wydawnicza „Impuls”, Kraków 2015.

[4] Chrzanowska I., Wiedza na temat autyzmu wśród obecnych i przysztych pedagogów a dylemat wspólnego ksztatcenia $i$ integracji w wymiarze edukacyjnym, „Rocznik Lubuski" 2012, Vol. 38, part 2, p. 112 (pp. 105-114).

[5] Evans J., Lunt I., Inclusive education: are there limits? "European Journal of Special Need Education", 2002, 17(1), pp. 1-14.

[6] Firkowska-Mankiewicz A., Szumski G., Pedagogika specjalna i system kształcenia osób z niepetnosprawnościami w Polsce, [in:] Pedagogika specjalna 2. Podręcznik akademicki, D. D. Smith, Wydawnictwo PWN, Warszawa 2009.

[7] Gałecki P., Święcicki Ł. (academic supervision, Polish ed.) Kryteria diagnostyczne z DSM 5: Desk Reference, Wydawnictwo Edra Urban \& Partner. Wrocław 2015.

[8] Głodkowska J., W poszukiwaniu modelu edukacji wtaczającej, „Meritum”, 2009, No. 2(13).

[9] Grzelak P., Kubicki P., Orłowska M., Realizacja badania ścieżek edukacyjnych niepetnosprawnych dzieci, uczniów i absolwentów. Raport końcowy, Educational Research Institute in Warsaw 2014.

[10] Janiszewska-Nieścioruk Z., (Nie)dojrzatość proinkluzyjnych zmian w ksztatceniu osób z niepetnosprawnościa, "Niepełnosprawność. Dyskursy pedagogiki specjalnej", 2016, No. 22, pp. 47-59.

[11] Klin A., Typologia zaburzeń ze spektrum. Aspekty teoretyczne, badawcze i kliniczne, [in:] Diagnoza zaburzeń ze spektrum autyzmu, ed. S. Goldstein, Jack A. Naglieri, S. Ozonoff, Wydawnictwo Uniwersytetu Jagiellońskiego, Kraków 2017.

[12] Klinger L.G., O'Kelly S.E., Mussey J.L., Diagnoza funkcjonowania intelektualnego w zaburzeniach ze spektrum autyzmu, [in:] Diagnoza zaburzeń ze spektrum autyzmu, ed. S. Goldstein, Jack A. Naglieri, S. Ozonoff, Wydawnictwo Uniwersytetu Jagiellońskiego, Kraków 2017. 
[13] Międzynarodowa Statystyczna Klasyfikacja Chorób i problemów Zdrowotnych. Rewizja 10 (International Statistical Classification of Diseases and Health Problems. Revision 10), WHO 2008, p. 248.

[14] Nason B., Porozmawiajmy o autyzmie. Przewodnik dla rodziców i specjalistów, Wydawnictwo Uniwersytetu Jagiellońskiego, Kraków 2017.

[15] Płatos M. (ed.), Ogólnopolski spis autyzmu. Sytuacja młodzieży i dorosłych z autyzmem $w$ Polsce, Wydawca Stowarzyszenie Innowacji Społecznych „Mary i Max”, Warszawa 2016.

[16] Olszewski S., Parys K., Rozumieć chaos. Rzecz o terminach $i$ znaczeniach im nadawanych w pedagogice specjalnej, Wydawnictwo Naukowe Uniwersytetu Pedagogicznego in Kraków, Kraków 2016.

[17] Rybakowski F., Białek A., Chojnicka I. et al., Zaburzenia ze spektrum autyzmu epidemiologia, objawy, wspótzachorowalność i rozpoznawanie, "Psychiatria Polska” 2014, 48(4), pp. 653-665.

[18] Rosenberg R.E., Kaufmann W.E., Law J.K., Law P.A., Parent Report of Community Psychiatric Comorbid Diagnoses in Autism Spectrum Disorders, "Autism Research and Treatment", 2011 Aug. 18, <https://www.ncbi.nlm.nih.gov/pmc/ articles/PMC3420588/> [access: 8 February 2018].

[19] Regulation of the Minister of National Education of 9 August 2017 on the conditions for organising education, upbringing and care for children and youth with disabilities, socially maladjusted and at risk of social maladjustment $\S 7$ section 7 and $\S 5$ section 4 (Journal of Laws of 2017, item 1578).

[20] Regulation of the Minister of National Education of 7 September 2017 on opinions and decisions issued by adjudicating panels operating in public psychological and pedagogical counselling centres; Journal of Laws of 2017, item 1743.

[21] Sansosti J. M., Sansosti F., Inclusion for Students with High-functioning Autism Spectrum Disorders: Definitions and Decision Making Psychology in the Schools, 2012, Vol. 49(10), pp. 917-931.

[22] Act of 14 December 2016 Education Law (Journal of Laws of 2017, item 59).

[23] <https://www.nadzor-pedagogiczny.pl/porada/jakie-kwalifikacje-musi-posia dac-nauczyciel-wspoma/9285/> [access: 29 May 2019]. 